Syntax Literate : Jurnal Ilmiah Indonesia p-ISSN: 2541-0849

e-ISSN: 2548-1398

Vol. 5, No. 5 Mei 2020

\title{
PELAYANAN PUBLIK DALAM PERSPEKTIF ADMINISTRASI PUBLIK DI INDONESIA
}

\section{Eka Septiani dan Ferry Siswadhi}

Sekolah Tinggi Ilmu Administrasi Nusantara Sakti (STIA NUSA) dan Sekolah Tinggi Ilmu Ekonomi Sakti Alam Kerinci (STIE SAK) Jambi

Email : ekaseptianistia@gmail.com dan fsiswadhi@gmail.com

\section{Abstract}

The purpose of this research is to determine the extent to which the government is responsive to its duties as a state servant. The method used in this research is library research where the approach used is qualitative and descriptive approaches. The result is got from this research is solution for resolve public service in Indonesia, that is with New Publik Service and Good Governance. This approach is considered right if is implemented in democracy country is like Indonesia. Beside that, With existence reformation in fields of service with expectations can be Alternative for countries towards developed countries in the political and economic fields so as to achieve public welfare.

Keywords: Problem, Quality, Public Service.

\begin{abstract}
Abstrak
Tujuan dari penelitian ini yaitu untuk mengetahui sejauh mana pemerintah responsif terhadap tugasnya sebagai pelayan negara. Adapun metode yang digunakan dalam penelitian ini yaitu studi literatur (library research) dimana pendekatan yang digunakan yaitu pendekatan kualitatif dan deskriptif. Hasil yang diperoleh dari penelitian ini adalah solusi dalam mengatasi pelayan publik di Indonesia, yaitu dengan New Publik Service dan Good Governance. Pendekatan ini di anggap tepat jika diterapkan di negara dekomratis seperti Indonesia ini. Selain itu, dengan adanya reformasi dalam bidang pelayanan ini diharapkan dapat menjadi alternatif negara menuju negara yang maju dibidang politik dan ekonomi sehingga mencapai kesejahteraan masyarakat.
\end{abstract}

Kata kunci: Masalah, Kualitas, Pelayanan Publik.

\section{Pendahuluan}

Pemerintahan desa merupakan kegiatan pelayanan yang dilakukan oleh kepala desa dan perangkat desa yang bertujuan untuk mensejahterakan masyarakat di desa (Muksin \& Sadikin, 2020). Melayani masyarakat adalah tujuan utama dalam mengimplementasikan administrasi public. Melihat Indonesia saat ini, penyelenggaraan pelayanan publik menjadi isu strategis karena cenderung belum ada perkembangan yang isgnifikan, sedangkan implikasinya bersifat sangat luas karena mencakup berbagai kehidupan seperti ekonomi, sosial, politik, budaya dan sebagainya. 
Dampk dari pelayanan publik yang buruk dalam bidang ekonomi yakni menurunnya investasi yang bisa mengakibatkan tidak ada lagi hubungan kerja antar industri dan hilangnya lapangan kerja baru yang bisa meningkatkan angka pengangguran di Indonesia.

Perbaikan pelayanan publik dapat menjadi solusi dalam mengatasi krisis ekonomi yang berkepanjangan dengan cara memperbaiki investasi yang sangat diperlukan bangsa. Tetapi hal tersebut masih sebatas lips service. Menurut hasil studi pelayanan publik di Indonesia belum dimanfaatkan secara maksimal, sehinga hasil yang didapat pun tidak sesuai dengan apa yang diharapkan bahkan dampak negatiflah yang ditimbulkan. Akibatnya rencana menolong bangsa dari krisis ekonomi belum terrealisasi dengan baik sesuai yang diharapkan. Dampak lain yang ditimbulkan dalam kehidupan politik adalah lemahnya kepercayaan masyarakat terhadap pemerintah.

Kepercayaan masyarakat ini menjadi variable penting dalam memperbaiki pelayanan publik. Tetapi, dengan adanya protes dan demonstrasi yang tidak sehat inilah menandakan buruknya pelayanan publik yang terjadi saat ini.

Sehubungan dengan hal tersebut mutlak adanya perbaikan pelayanan publik agar adanya harmonisasi dalam aktifitas sehari-hari. Jika pelayanan publik yang diberikan terhadap masyarakat itu baik, maka kepercayaan masyarakat pun akan menjadi energi dalam proses pelayanan publik itu sendiri.

Dari segi sosial budaya, pelayanan publik yang buruk mengakibatkan terganggunya psikologi masyarakat yang terindikasi dari berkurangnya rasa saling menghargai dikalangan masyarakat, timbulnya saling curiga meningkatnya sifat eksklusifisme yang berlebihan, yang pada akhirnya menimbukan ketidakpedulian antar masyarat itu sendiri maupun dengan pemerintah setempat. Adanya kerusuhan yang bersifat anarkis merupakan bentuk nyata dari kurangnya rasa kepedulian tersebut. Seiring dengan itu masyarakat cenderung berfikir praktis mengarah kepada hal negatif dengan ragam tindakan yang tidak rasional dan cenderung melanggar hukum.

\section{Metode Penelitian}

Metode penelitian yang dipergunakan dalam penulisan artikel ilmiah ini adalah dengan menggunakan metode studi literatur (library research) dengan menggunakan analisis kualitatif dan deskriptif yaitu dengan menguraikan pemikiran atau opini penulis, dan selanjutnya menjelaskan keterkaitannya dengan teori-teori para ahli serta beberapa penelitian terdahulu sehingga diharapkan dapat menghasilkan pemikiran yang lebih baik lagi berkenaan dengan fokus bahasan.

\section{Hasil dan Pembahasan}

\section{Pengertian dan Konteks Pelayanan Publik}

Pelaksanaan pelayanan publik pada prinsipnya ditujukan kepada manusia. Manusia sebagai mahluk sosial akan sangat membutuhkan pelayanan dari manusia lain dalam proses kehidupannya. Dengan kata lain, manusia dan pelayanan tidak dapat dipisahkan satu sama lain. Sejak lahirnya manusia sudah membutuhkan 
pelayanan, sebagaimana dikemukakan (Rusli, 2004) bahwa manusia selalu membutuhkan pelayanan selama hidupnya. Istilah yang digunakan oleh Rusli ini Menurut Rusli life cycle theory of leadership sejak manusia dilahirkan manusia mendapatkan pelayanan yang sangat tinggi terhadap fisiknya. Semakin bertambah usia manusia akan semakin menurun pelayanan yang dibutuhkan.

Setiap hari tuntutan masyarakat yang dilontarkan kepada birokrat adalah pelayanan publik yang berkualitas. Namun seringkali hasil yang didapat tidak sesuai harapan. Adanya proses yang lamban, berbelit-belit, melelahkan, mahal dan ketidakpastian yang didapat oleh masyarakat. Keadaan demikian menunjukan bahwa yang dilayani adalah birokrat itu sendiri bukan masyarakat.

Kata demi kata dalam pelayanan public dapat ditelaan dengan cara konseptual. Menurut Kotler sebagaimana dikutip oleh (Lukman, Maskoen, Achmad, Hanafi, \& Karnadihardja, 2000) disebutkan bahwa Pelayanan adalah setiap kegiatan yang menguntungkan dalam suatu kumpulan atau kesatuan, dan menawarkan kepuasan meskipun hasilnya tidak terikat pada suatu produk secara fisik. Dalam UndangUndang Nomor 25 Tahun 2009 tentang Pelayanan Publik disebutkan pengertian pelayanan publik sebagai kegiatan atau rangkaian kegiatan dalam rangka pemenuhan kebutuhan pelayanan sesuai dengan peraturan perundang-undangan bagi setiap warga negara dan penduduk atas barang, jasa, dan/atau pelayanan administratif yang disediakan oleh penyelenggara pelayanan publik.

Pelayanan publik pada dasarnya menyangkut aspek kehidupan yang sangat luas. Dalam kehidupan bernegara, maka pemerintah memiliki fungsi memberikan berbagai pelayanan publik yang diperlukan oleh masyarakat, mulai dari pelayanan dalam bentuk pengaturan ataupun pelayanan-pelayanan lain dalam rangka memenuhi kebutuhan masyarakat dalam bidang pendidikan, kesehatan, utilitas, dan lainnya (Elia et al., 2003).

Pada awal tahun 1990-an reformasi public telah dilakukan oleh negara-negara maju, hal ini terbentuk karena adanya tekanan dari masyarakat terkait kualitas pelayanan pemerintah pada saat itu. Contohnya Amerika Serikat yang mengembangkan proses pelayanan publik ini dengan karya ilmiah yang di tulis para pakar dengan munculnya paradigma postbureaucratic oleh (Barzelay, 1992) bersama dengan (Barzelay \& Armajani, 1997) Pandangan postbureacratic berkaitan dengan pelayanan publik terlihat pada penekanan administrasi publik pada hasil yang berguna bagi masyarakat, kualitas dan nilai, produk dan keterikatan terhadap norma, dan mengutamakan misi, pelayanan dan hasil akhir (outcome).

Dalam kurun waktu yang hamper bersamaan muncul paradigma reinventing government oleh Osborne dan Gaebler (Keban, 2008) selanjutnya paradigma ini di operasionalkan pada tahun 1997 oleh Osborne dan Plastrik dalam karyanya Banishing Bureaucracy: The Five Strategies for Reinventing Government. Nama lain dari paradigma ini adalah New Public Management. Penekanan dalam paradigma ini yaitu memberikan pemahaman yang seharusnya. Yakni pemerintahlah yang harus melayani masyarakat dengan baik. 
Penjelasan lain dijelaskan melalui karya J.V. Denhardt dan R.B. Denhardt dalam bukunya The New Public Service (2003). Pandangan dari paradigma tersebut erat kaitannya dengan pelayanan yakni administrasi publik hendaknya melayani warga bukan mengendalikan warga. Menurut paradigma new public service pelayanan publik harus sangat respondif terhadap kepentingan publik. Tugas pemerintah adalah melakuakan negosiasi dan mengelaborasi berbagai kepentingan warga negara dan beberapa kelompok komunitas. Perkembangan masyarakat akan selalu dinamis untuk itu pemerintah harus senantiasa mengikuti perkembangan masyarakat. Selain itu pelayanan publik model baru ini harus bersifat nondiskriminatif sebagaimana dimaksud oleh dasar teoritis yang digunakan yaitu teori demokratis yang menjamin adanya persamaan warga negara tanpa membeda-bedakan asal-usul, kesukuan, ras, etnik, agama, dan latar belakang kepartaian (Dwiyanto, 2005).

\section{Masalah-Masalah Pelayanan Publik Di Indonesia}

Terlepas dari berbagai teori, pendekatan, perspektif dan paradigma berkaitan dengan pelayanan publik yang senantiasa berubah untuk menyesuaikan diri dengan dinamika perkembangan kebutuhan masyarakat yang terdapat di negara-negara maju atau pada belahan dunia lainnya. Pergeseran tersebut bertujuan untuk menciptakan suatu kerangka pelaksanaan pelayanan publik yang lebih baik, efisien, responsive, dan berorientasi pada kepentingan masyarakat.

Bagi negara sedang berkembang termasuk di Indonesia gelombang tekanan untuk mengubah wajah pemerintahan dan substansi operasi mesin pelayanan publiknya tidak terlepas dari tekanan-tekanan dari lembaga-lembaga internasional seperti misalnya IMF, World Bank, atau lembaga donor lainnya. Hal tersebut tidak terlepas dari kepentingan lembaga-lembaga tersebut yang beroperasi di Indonesia.

Adanya tuntutan perbaikan pelayanan publik tersebut kadangkala menjadi prasyarat utama oleh lembaga-lembaga internasional atau negara-negara donor tersebut dalam memberikan bantuan (loan). Seperti IMF dan World Bank, kedua lembaga keuangan yang amat berpengaruh tersebut sejak hampir dua dekade terakhir ini semakin rajin mendesakkan tuntutan politik terhadap negara-negara berkembang untuk mendevolusikan sistem pemerintahan dan sistem pelayanan publiknya yang monopolistik dengan menganjurkan kebijakan pemerkuatan otonomi daerah, privatisasi sektor publik dan pemberian kesempatan yang luas pada sektor-sektor di luar birokrasi pemerintah. (Abdul-Wahab \& Khalil, 2000) menelusuri permasalahan pelayanan publik di Indonesia sebenarnya dapat dilihat pada beberapa periode dalam penyelenggaraan pemerintahan, misalnya dimulai pada masa orde baru dan terakhir periode reformasi. Pergeseran paradigma dalam pelayanan publik tidak dilepaskan dari perubahan iklim politik yang berimplikasi pada kebijakan-kebijakan yang dibuat dan dilaksanakan oleh pemerintah. Di Indonesia pada masa orde baru misalnya pelayanan publik ditandai oleh dominasi negara pada berbagai elemen-elemen kehidupan 
bangsa, sehingga pada masa ini dikenal dengan paradigma negara kuat atau negara otonom dimana kekuatan sosial politik termasuk kekuatan pasar kecil pengaruhnya dalam kebijakan publik, bahkan dalam pelaksanaannya.

Dalam era reformasi ditandai pada paradigma deregulasi setengah hati, dimana pemerintah memilih sektor tertentu untuk dideregulasi yang pertimbangan utamanya bukan pencapaian efisiensi pelayanan publik, tetapi keamanan bisnis antara pejabat negara dan pengusaha besar. Kemudian pada paradigma reformasi pelayanan publik. Paradigma ini mengkaji ulang peran pemerintah dan mendefinisikan kembali sesuai dengan konteksnya, yaitu perubahan ekonomi dan politik global, penguatan civil society, good governance, peranan pasar dan masyarakat yang semakin besar dalam penyusunan dan pelaksanaan kebijakan publik.

Sekalipun di Indonesia secara politik era reformasi itu sudah berjalan sekitar 10 tahun sejak lengsernya Presiden Suharto pada tahun 1998, namun dalam penyelenggaraan pelayanan publik masih ditandai berbagai kelemahan-kelemahan, padahal sudah banyak upaya yang telah dilakukan oleh pemerintah dalam upaya meningkatkan pelayanan kepada masyarakat antara lain perumusan kembali Undang-Undang tentang Pemerintahan Daerah yang sebenarnya memberikan perluasan kewenangan pada tingkat pemerintah daerah, dipandang sebagai salah satu upaya untuk memotong hambatan birokratis yang acapkali mengakibatkan pemberian pelayanan memakan waktu yang lama dan berbiaya tinggi. Dengan adanya desentralisasi daerah mau tidak mau harus mampu melaksanakan berbagai kewenangan yang selama ini dilaksanakan oleh pemerintah pusat, seiring dengan pelayanan yang harus disediakan.

Upaya untuk memperbaiki pelayanan telah sejak lama dilaksanakan oleh pemerintah, antara lain kebijakan ini dapat dilihat pada Surat Keputusan Menteri Pendayagunaan Aparatur Negara Nomor 81/1993 tentang Pedoman Tatalaksana Pelayanan Umum. Kemudian Inpres No. 1 Tahun 1995 tentang perbaikan dan peningkatan mutu pelayanan apartur pemerintah kepada masyarakat. Pada perkembangan terakhir telah diterbitkan pula Keputusan Menpan Nomor 63/KEP/M.PAN/7/2003 tentang Pedoman Umum Penyelenggaraan Pelayanan Publik. Upaya meningkatkan kualitas pelayanan tidak hanya ditempuh melalui keputusan-keputusan, tetapi juga melalui peningkatan kemampuan aparat dalam memberikan pelayanan. Upaya ini dilakukan dengan cara memberikan berbagai materi mengenai manajemeni pelayanan dalam diklat-diklat struktural pada berbagai tingkatan.

Hanya saja dari berbagai upaya yang dilakukan oleh pemerintah untuk memperbaiki pelayanan publik, namun masih saja ditemukan berbagai kelemahan dalam pelayanan publik ini. Hal tersebut dapat dilihat pada hasil survay yang dilakukan oleh UGM pada tahun 2002 diketahui bahwa dilihat dari sisi efisi ensi dan efektivitas, responsivitas, kesamaan perlakuan dan besar kecilnya rente birokrasi masih jauh dari yang diharapkan (Elia et al., 2003). 
Oleh sebab itu, dengan membandingkan upaya-upaya yang telah ditempuh oleh pemerintah dengan kondisi pelayanan publik yang dituntut dalam era desentralisasi, tampaknya upaya pemerintah tersebut masih belum banyak memberikan kontribusi bagi perbaikan kualitas pelayanan publik itu sendiri. Bahkan birokrasi pelayanani publik masih belum mampu menyelenggarakan pelayanan yang adil dan non-partisan.

Jika diperhatikan berbagai permasalahan penyelenggaraan pelayanan publik di Indonesia, maka permasalahan utama pelayanan publik sekarang ini adalah berkaitan dengan peningkatan kualitas dari pelayanan itu sendiri. Menurut (Zemke \& Schaaf, 1990) kualitas pelayanan publik merupakan hasil interaksi dari berbagai aspek, yaitu sistem pelayanan, sumber daya manusia pemberi pelayanan, strategi, dan pelanggan.

Dilihat dari sisi pola penyelenggaraannya, pelayanan publik di Indonesia masih memiliki berbagai kelemahan antara lain: (1) kurang responsive (2) kurang informatif (3) kurang accessible(4) kurang koordinasi(5) birokratis(6) kurang mau mendengar keluhan/saran/aspirasi masyarakat, dan (7) inefisiensi. Dilihat dari sisi sumber daya manusianya kelemahan utamanya adalah berkaitan dengan profesionalisme, kompetensi, emphaty dan etika. Pola kerja yang digunakan oleh sebagian besar aparatur yang ada sekarang ini masih dipengaruhi oleh model birokrasi klasik, yakni cara kerja yang terstruktur/hierarkis, legalistik formal, dan sistem tertutup. Selain itu beberapa pendapat menilai bahwa kelemahan sumber daya manusia aparatur pemerintah dalam memberikan pelayanan disebabkan oleh sistem kompensasi yang rendah dan tidak tepat.

Kelemahan pelaksanaan pelayanan publik lainnya dapat dilihat pada sisi kelembagaan, kelemahan utama terletak pada disain organisasi yang tidak dirancang khusus dalam rangka pemberian pelayanan kepada masyarakat, penuh dengan khirarki yang membuat pelayanan menjadi berbelit-belit (birokratis), dan tidak terkoordinasi. Kecenderungan untuk melaksanakan dua fungsi sekaligus, fungsi pengaturan dan fungsi penyelenggaraan, masih sangat kental dilakukan oleh pemerintah, yang juga menyebabkan pelayanan publik menjadi tidak efisien.

\section{Pilihan Perspektif Administrasi dalam mengatasi masalah Pelayanan Publik}

Sebagaimana diketahui perkembangan ataupun pergeseran paradigma dalam administrasi publik senantiasa berlangsung sesuai dengan tuntutan lingkungan, seperti situasi dan kondisi sosial kemasyarakatan, perubahan iklim politik, dan ekonomi. Berbagai perubahan terjadi seiring dengan berkembangnya kompleksitas persoalan yang dihadapi oleh administrator publik. Kompleksitas ini ditanggapi oleh para teoritisi dengan terus mengembangkan ilmu administrasi publik.

(Denhardt \& Denhardt, 2003) mengungkapkan bahwa terdapat tiga perspektif dalam administrasi publik. Perspektif tersebut adalah old public administration, new public management, dan new public service. Berdasarkan perspektif yang dikemukakan oleh Denhardt dan Denhardt sebagai pencetus perspektif baru 
administrasi publik yakni new public service, kedua ahli ini menyarankan untuk meninggalkan prinsip administrasi klasik dan new public management yang termasyhur dengan reinventing governementnya, dan beralih ke prinsip new public service. Menurut (Denhardt \& Denhardt, 2003) administrasi publik harus:

a. Melayani warga masyarakat bukan pelanggan.

b. Mengutamakan kepentingan publik.

c. Lebih menghargai kewarganegaraan dari pada kewirausahaan.

d. Berpikir strategis dan bertindak demo- kratis.

e. Menyadari bahwa akuntabilitas bukan sesuatu yang mudah.

f. Melayani daripada mengendalikan.

g. Menghargai orang, bukannya produktivitas semata.

Pandangan yang mirip dengan perspektif yang dikemukakan Denhardt dan Denhardt tersebut sekalipun dengan nama yang berbeda adalah perspektif yang dikemukakan oleh Bovaird dan Loffler (2003) bahwa terdapat tiga pendekatan dalam administrasi publik yaitu public administration, public management, dan public governance. Sementara G. Shabbir Cheema (2007) sebagaimana dikutip oleh (Keban, 2008) mengemukakan empat fase administrasi publik yang juga menggambarkan perkembangan administrasi publik yaitu: traditional public administration, public management, newpublicmanagement, dan governance. Paradigma terakhir yang dikemukakan oleh Cheema tersebut yakni governance mendapatkan perhatian yang besar dari berbagai negara melalui ajakan UNDP dengan menggunakan istilah Good Governance, adapun karakteristik good governance dari UNDP meliputi (Keban, 2008):

a. Participation yaitu bahwa semua orang harus diberi kesempatan yang sama untuk mengemukakan pendapatnya dalam pengambilan keputusan baiki langsung atau melalui perantara institusi yang mewakili kepentingannya.

b. Rule of law, yaitu bahwa aturan hukum harus adil dan ditegakkan tanpa pandang bulu.

c. Transparancy, yaitu bahwa keterbukaan harus dibangun diatas aliran informasi yang bebas.

d. Responsiveness, yaitu bahwa institusi-institusi dan proses yang ada harus diarahkan untuk melayani para stakeholders.

e. Consensus orientation yaitu bahwa harus ada proses mediasi untuk sampai kepada konsensus umum yang didasarkan atas kepentingan kelompok, dan sedapat mungkin didasarkan pada kebijakan dan prosedur.

f. Equity, yaitu bahwa semua orang memiliki kesempatan yang sama untuk memperbaiki dan mempertahankan kesejahteraannya.

g. Effectiveness and efficiency, yaitu bahwa proses dan institusi-institusi yang ada sedapat mungkin memenuhi kebutuhan masyarakat melalui pemafaatan terbaik terhadap sumberdaya-sumberdaya yang ada.

h. Accountability, yaitu bahwa para pengambil keputusan di instansi pemerintah, sektor publik dan organisasi masyarakat madani harus mampu 
mempertanggungjawabkan apa yang dilakukan dan diputuskannya kepada publik sekaligus kepada para pemangku kepentingan.

i. Strategic vision yaitu bahwa para pemimpin dan masyarakat publik harus memiliki perspektif yang luas dan jangka panjang terhadap pembangunan manusia, dengan memperhatikan latar belakang sejarah, dan kompleksitas sosial budaya.

Mencermati beberapa perspektif yang dikemukakan oleh para ahli tersebut, dan upaya untuk mengatasi masalah-masalah berkaitan dengan pelaksanaan pelayanan publik di Indonesia sesuai dengan perkembangan IPTEK, kemajuan pengetahuan masyarakat serta perubahan iklim politik yang lebih demokratis, maka perspektif administrasi publik yang relevan dapat diterapkan adalah perspektif new public sevice (NPS) dan governance. NPS sebagai paradigma terbaru dari administrasi publik meletakkan pelayanan publik sebagai kegiatan utama para administratur publik. Pelayanan dalam konteks ini berbeda dengan pelayanan berbasis pelanggan (konsumen) sebagaimana digagas oleh dalam pradigma New Public Management (NPM). NPM menurut (Denhardt \& Denhardt, 2003) didasarkan pada public choice theory, dimana teori tersebut menekankan pada kemampuan individu seseorang dibandingkan dengan kemampuan publik secara bersama-sama.

Penggunaan perspektif New Public Service dalam mengatasi masalah pelayanan publik di Indonesia hal ini juga sesuai dengan dasar negara Pancasila khususnya pada Sila keempat dan kelima, yang menekankan pada musyawarah mufakat dalam hal ini adanya kesepakatan antara pemerintah selaku pemberi layanan dengan warga sebagai penerima layanan, sedangkan pada aspek keadilan sosial hal ini menunjukkan bahwa pemberian pelayanan kepada masyarakat harus dilandaskan pada aspek keadilan dalam pengertian tidak boleh ada diskriminasi atau perbedaan yang didasarkan pada alasan-alasan ekonomi, politik, dan alasan yang tidak rasional lainnya. Salah satu intisari dari prinsip NPS tersebut adalah bagaimana administrator publik mengartikulasikan dan membagi kepentingan warga negara (Denhardt \& Denhardt, 2003) Agar kepentingan warga negara tersebut dapat terbagi rata, diperlukan media pertemuan antara pemerintah dengan warga masyarakat, sehingga semua kepentingan warga masyarakat dapat diakomodasi.

Upaya untuk meningkatkan kualitas pelayanan publik ini, beberapa kegiatan sudah dilakukan oleh pemerintah misalnya dapat dilihat pada kegiatan perencanaan partisipatif seperti musyawarah pembangunan (Musren bang) baik pada tingkat kecamatan, kabupaten, maupun provinsi dan nasional. Meskipun demikian kegiatan tersebut tidak dapat diselenggarakan sewaktu-waktu, sehingga kepentingan masyarakat dalam bentuk kebutuhan tidak dapat ditangkap dengan cepat oleh pemerintah. Seperti kebutuhan yang terjadi secara tiba-tiba seperti kebutuhan akan kesehatan, air bersih, bisa terjadi sewaktu-waktu. Agar kebutuhan masyarakat dapat segera diantisipasi dan diatasi oleh pemerintah maka diperlukan media komunikasi antara pemerintah dan masyarakat. Sesuai dengan perspektif New 
Publici Service maupun good governance, ada beberapa model pelayanan publik yang dapat digunakan untuk mengatasi masalah pelayanan publik di Indonesia diantaranya adalah:

a. Model Citizen's Charter (kontrak pelayanan), model ini berasal dari ide (Osborne \& Plastrik, 1997) Dalam model ini terdapat standar pelayanan publik yang ditetapkan berdasarkan masukan warga masyarakat, dan aparat pemerintah ber- janji untuk memenuhinya dan melaksanakannya. Model ini merupakan pendekatan dalam pelayanan publik yang memposisikan pengguna layanan sebagai pusat perhatian. Oleh sebab itu, kebutuhan dan kepentingan pengguna layanan harus menjadi pertimbangan utama dalam proses pelayanan. Citizen's Charter ini dapat dikatakan sebagai kontrak sosial antara warga dengan aparat birokrasi untuk menjamin mutu pelayanan publik. Adanya kontrak sosial tersebut, maka warga memiliki hak-hak baru apabila dirugikan oleh birokrasi dalam memberikan pelayanan. Dengan mengadopsi model Citizen's Charter, birokrasi juga harus menetapkan sistem untuk menangani keluhan pelanggan dengan tujuan memperbaiki kinerjanya secara terus menerus.

b. Model KYC (Know Your Costumers), model ini dikembangkan dalam dunia perbankan yang dapat diadaptasi ke dalam konteks pelayanan publik dalam organisasi pemerintah. Mekanisme kerja dalam model ini yaitu berupaya mengenali terlebih dahulu kebutuhan dan kepentingan pelanggan sebelum memutuskan jenis pelayanan yang akan diberikan (Dwiyanto, 2005). Untuk mengetahui keinginan, kebutuhan dan kepentingan pengguna layanan, maka birokrasi pelayanan publik harus mendekatkan diri dengan masyarakat. Beberapa metode yang dapat digunakan untuk mengetahui keinginan dan kebutuhan para pelanggan yaitu melalui survai, wawancara, dan observasi. Jika menggunakan metode survai maka seperangkat daftar pertanyaan harus disusun untuk mengidentifikasi keinginan, kebutuhan, dan aspirasi masyarakat terhadap pelayanan yang diinginkan. Dalam model KYC ini birokrasi pemerintah harus mengetahui siapa yang menjadi pelanggannya (orang atau kelompok masyarakat yang dilayani). Oleh sebab itu setiap unit birokrasi pemerintah harus mampu mendefinisikan pelanggannya atau pengguna jasa mereka, sehingga untuk selanjutnya mereka dapat mengorientasikan pelayanan kepada kebutuhan masyarakat pengguna jasa tersebut. Kantor kelurahan misalnya harus mampu mengidentifikasi pengguna jasa mereka, apakah masyarakat yang ada dalam wilayah kelurahannya, ataukah camat dan bupati yang mengangkat lurah tersebut.

c. Model M-Government ( $m$-Gov), kemajuan teknologi dibidang informasi dan komunikasi ikut berpengaruh secara langsung maupun tidak langsung terhadap kinerja birokrasi pemerintah terutama dari segi pelayanan warga masyarakat. M-Government sebenarnya diadaptasi dari Electronic Government (e-Gov) yakni salah satu cara untuk menjalankan fungsi pemerintah dengan memanfaatkan berbagai perangkat teknologi informasi dan komunikasi (TIK) (Nugroho, 2008) 
Menurut (Kushchu \& Kuscu, 2003) bahwa penggunaan e-Gov setidaknya mampu mengubah pola interaksi antara pemerintah dengan masyarakat. Pelayanan yang semula berorientasi pada antrian (in line) di depan meja pegawai dan tergantung pada jam kerja serta person pegawai yang menangani suatu pelayanan tertentu berubah menjadi layanan on line yang dapat diakses website pemerintah melalui komputer yang terhubung ke internet, selama 24 jam sehari. Konsep pemerintah yang menggunakan teknologi bergerak tersebut disebut Mobile Government(m-Gov). Model ini pada saat sekarang sudah dapat digunakan dengan mudah karena fasilitas yang dipergunakan dapat melalui komputer PC di rumah atau di kantor, Laptop/note- book/tablet, dan Hp (Mobile Phone). m- Gov adalah strategy and its implementation involving the utilization of all kinds of wireless and mobile technology, services, applications and devices for improving benefits to the parties involved in e-government including citizens, businesses and government units (Kushchu \& Kuscu, 2003).

Beberapa daerah di Indonesia sudah mengimplementasikan e-Gov ini seperti Kota Solo dan Kabupaten Sragen. Juga Presiden SBY menggunakan e-Gov dalam memberikan pelayanan seperti membuka layanan SMS pada nomor 9949 untuk menerima keluhan masyarakat, juga KPK (Komisi Pemberantasan Korupsi) menerima pengaduan masyarakat mengenai kasus-kasus korupsi melalui fasilitas SMS. Ada beberapa cara yang dapat digunakan dalam mengimplementasikan $m$ Gov ini seperti melalui jaringan internet dengan menggunakan laptop, kini sudah banyak tersedia jaringan $\mathrm{WiFi}$ (wireless fidelity) yakni perangkat yang memungkinkan pengguna untuk mengakses internet secara nirkabel bahkan beberapa lokasi tersedia hotspot gratis. Cara lain yang dapat digunakan dalam implementasi $m$-Gov ini yaitu melalui handphone baik penggunaan melalui suara atau SMS (short massage service).

Pemanfaatan suara melalui telepon atau Hp (mobile phone) untuk menerima kebutuhan dari masyarakat sudah sering digunakan di dunia bisnis dengan nama Call Centre, pada institusi perbankan dikenal dengan nama phone banking. Untuk organisasi publik, konsep ini diterapkan dengan pegawai sebagai agen.

Nantinya agen ini akan memberikan informasi tentang kebutuhan masyarakat. Selain berfungsi sebagai garda terdepan dalammemberikan pelayanan informasi kepada masyarakat, agen ini juga dapat berfungsi sebagai penghubung aspirasi antara masyarakat dengan pemerintah. Kebutuhan masyarakat dimasukkan ke dalam sistem yang terintegrasi sehingga dapat diketahui oleh pimpinan instansi. Melalui fasilitas SMS di Hp yaitu fasilitas yang dapat digunakan untuk mengirim dan menerima pesan-pesan pendek. Ada beberapa bentuk dari penggunaan teknologi ini di pemerintahan (Nugroho, 2008) antara lain:

a. Pemerintah ke masyarakat, dalam hal ini pemerintah dapat memberikan informasi kepada warganya melalui SMS. 
b. Masyarakat ke pemerintah, keluhan dan saran masyarakat dapat dikirimkan ke pemerintah melalui SMS. Menurut (Lallana, 2004) untuk poin a dan b di atas disebut $m$-Communication.

c. Pemerintah ke pegawai negeri sipil, memberikan pengumuman kepada PNS melalui SMS, sehingga informasi dapat lebih cepat diterima dan akhirnya pelayanan kepada masyarakat dapat lebih cepat. Kemampuan lain dari ponsel adalah mampu memberikan lokasi dimana PNS berada, ini diperlukan untuk mengetahui keberadaan pegawai jika mereka tidak berada di kantor. Untuk hal ini menurut (Lallana, 2004) disebut m-Administration.

Ada beberapa cara atau pola yang dapat dilakukan untuk mengefektifkan model pelayanan $M-G o v$ ini, konsep yang ditawarkan oleh (Nugroho, 2008) adalah:

a. Masyarakat dengan Basis Data Aduan Masyarakat

b. Basis Data Aduan Masyarakat dengan Pemerintah Daerah

c. Basis Data Aduan Masyarakat dengan DPRD

d. Sistem Aduan Masyarakat dengan Forkompida

e. Sistem internal Pemda via SMS

\section{Kesimpulan}

Perspektif New Publik Service dan Good Governance dianggap paling tepat untuk kondisi sekarang dalam mengatasi masalah-masalah pelayanan publik di Indonesia. Hal itu didukung oleh situasi politik yang lebih demokratis dan keterbukaan pemerintah. Dan untuk efektifnya implementasi persepektif tersebut, dapat diterapkan dengan menggunakan beberapa model seperti model citizen's charter, model KYC (Know Your Customer) dan model m-Government. Dengan adanya model-model tersebut di atas diharapkan kendala-kendala yang selama ini menghambat efektivitas pelaksanaan pelayanan publik dapat diatasi sehingga pelaksanaan pelayanan publik dapat ditingkatkan efektivitasnya, sekalipun demikian kesemuanya kembali kepada person atau pelaksana pelayanan tersebut yakni aparat pemerintah dan juga partisipasi masyarakat. 


\section{BIBLIOGRAFI}

Abdul-Wahab, Hashim M. S., \& Khalil, Mohammad H. (2000). Rigidity and strength of orthotropic reinforced concrete waffle slabs. Journal of Structural Engineering, 126(2), 219-227.

Barzelay, Michael. (1992). Breaking through bureaucracy: A new vision for managing in government. Univ of California Press.

Barzelay, Michael, \& Armajani, Babak J. (1997). Innovation in the Concept of Government Operations. Innovation in American Government: Challenges, Opportunities, and Dilemmas, 119.

Denhardt, Robert B., \& Denhardt, Janet V. (2003). The new public service: An approach to reform. International Review of Public Administration, 8(1), 3-10.

Dwiyanto, Agus. (2005). Mewujudkan good governance melalui pelayanan publik. Gadjah Mada University Press.

Elia, Andrew E. H., Rellos, Peter, Haire, Lesley F., Chao, Jerry W., Ivins, Frank J., Hoepker, Katja, Mohammad, Duaa, Cantley, Lewis C., Smerdon, Stephen J., \& Yaffe, Michael B. (2003). The molecular basis for phosphodependent substrate targeting and regulation of Plks by the Polo-box domain. Cell, 115(1), 83-95.

Keban, Yeremias T. (2008). Enam Dimensi Strategis Administrasi Publik: Konsep, Teori, dan Isu, Edisi Kedua. Cetakan Pertama. Yogyakarta: Penerbit Gaya Media.

Kurniawan, Agung. (2005). Transformasi pelayanan publik. Pembaruan.

Kushchu, Ibrahim, \& Kuscu, Halid. (2003). From E-government to M-government: Facing the Inevitable. The 3rd European Conference on E-Government, 253-260. Citeseer.

Lallana, E. (2004). eGovernment for development, mGovernment definitions and models. Institute for Development Policy and Management. Http://Www. Egov4dev. Org/Mgovden. Htm.

Lukman, K., Maskoen, A. M., Achmad, T. H., Hanafi, B., \& Karnadihardja, W. (2000). Telomerase activity in different clinical staging of colorectal adenocarcinoma. Gan to Kagaku Ryoho. Cancer \& Chemotherapy, 27, 491-497.

Muksin, Ahmad, \& Sadikin, Samsu. (2020). Kualitas Pelayanan Izin Mendirikan Bangunan Rumah Tinggal di Dinas Penanaman Modal dan Pelayanan Terpadu Satu Pintu Kota Depok Tahun 2016-2018. Syntax Literate; Jurnal Ilmiah Indonesia, 5(1), 9-16.

Nugroho, Bunafit. (2008). Latihan Membuat Aplikasi Web PHP dan MySQL dengan Dreamweaver MX $(6,7,2004)$ dan 8. Yogyakarta: Gava Media. 
Pelayanan Publik dalam Perspektif administrasi Publik

Osborne, David, \& Plastrik, Peter. (1997). Banishing Bureaucracy: The Five Strategies for Reinventing Government. ERIC.

Rusli, Hardijan. (2004). Hukum ketenagakerjaan, 2003. Ghalia Indonesia.

Zemke, Ron, \& Schaaf, Dick. (1990). The service edge: 101 companies that profit from customer care. Plume Books. 